\title{
LABDARÚGÓ TELJESÍTMÉNY ELEMZÉSÉNEK IT ESZKÖZEI
}

\section{IT TOOLS OF SOCCER PERFORMANCE ANALYSIS}

\author{
Karikás Krisztián" ${ }^{1}$ Ráthonyi Gergely ${ }^{2}$ \\ ${ }^{1}$ Debreceni Egyetem, Gazdaságtudományi Kar, Sport-és rekreációszervezés szak, BSc hallgató, Debrecen \\ ${ }^{2}$ Debreceni Egyetemi, Gazdaságtudományi Kar, Alkalmazott Informatika és Logisztika Intézet, Debrecen
}

\section{Összefoglaló}

A világ töretlenül legnépszerübb sportja a labdarúgás, melyet jól reprezentál, hogy a 2018-as oroszországi labdarúgó világbajnokságot a világ lakosságának több mint fele követte valamilyen platformon. Egy-egy győzelem érdekében a csapatok mindent elkövetnek, hogy versenyelönyt alakíthassanak $\mathrm{ki}$ a vetélytársaikkal szemben. Az információtechnológia az egyik olyan robbanásszerüen fejlődő terület, mely a labdarúgásban is jelentôs változásokat eredményezett. Például innovatív megoldások jelentek meg a sportszergyártásban, melyek hozzájárultak a játék felgyorsulásához, a labdarúgó közvetítésekben megjelenő technológiai innovációk révén (3 dimenziós visszajátszás) növelhető a szurkolói élmény, vagy a nemrég bevezetett videóbíró és gólvonal-technológia pedig a vitatott szituációkat hivatottak eldönteni. A labdarúgásban kiemelkedő szerepe lehet a mérkőzéselemzésnek és az abból szármató adatoknak, melyek a játékosok és a csapat teljesítményét jellemzik, melyet több oldalról is vizsgálhatunk: technikai, taktikai, mentális és élettani. A technológia fejlődése révén a labdarúgásban dolgozó szakemberek számára jelentős mennyiségü, változó formátumú adat vált elérhetôvé, melynek feldolgozás és felhasználása kulcsfontosságú számukra.

Jelen cikk elsődleges célkitüzése, hogy bemutassa a teljesítményelemzés informatikai eszközrendszerét és jelentöségét a labdarúgásban.

Kulcsszavak: labdarúgás, mérkőzéselemzés, videóelemzés, információtechnológia

\section{Abstract}

Soccer is the world's most popular sport, well represented by the fact that the 2018 Russian Soccer World Cup has been followed by more than half of the world's population on some platform. For each win, teams do their best to create a competitive advantage over their rivals. Information technology is one of the explosive fields that has led to significant changes in soccer as well. For example, innovative solutions have emerged in the sports industry that have contributed to the acceleration of the game, technological innovations in soccer streaming can enhance the fan experience with up to 3-dimensional replays, or recently introduced video referee and goal line technology to solve disputed situations. In soccer, the analysis of the match and the resulting data that characterizes the performance of the players and the team, which can be analyzed from many angles: technical, tactical, mental and physiological, can play an important role. The advancement of technology has made it possible for soccer professionals to access significant amounts of variable format data, the processing and utilization of which is crucial to them.

The primary objective of this article is to present the importance of IT tools of performance analysis in soccer.

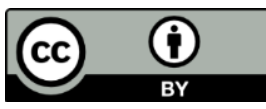


Vol 3, No 1 (2020): Stadium -Hungarian Journal of Sport Sciences https://doi.org/10.36439/SHJS/2020/1/5429

Keywords: soccer, match analysis, video analysis, information technology 


\section{BEVEZETÉS}

Annak érdekében, hogy be tudjuk azonosítani a sportsikereket akadályozó tényezőket a labdarúgásban, a mérkőzéselemzésnek feltételezhetően nagy szerepe van. Egy labdarúgó mérkőzésen több terület oldaláról is megközelíthetjük a teljesítményt: különböző technikai, taktikai szempontok, mentális állapotok és egyéb élettani funkciók mentén (GONZÁLEZ, 2013). A tudományos világban a sporttal, de kifejezetten a labdarúgással kapcsolatos teljesítmény elemzéssel foglalkozó publikációk száma az 1990-es években emelkedett jelentősen, amikor megjelentek a témában úttörő tudományos folyóiratok (MACKENZIE - CUSHION, 2012). Ezzel egyidejűleg fontos megemlíteni a technológia robbanásszerű fejlődését, mely az élet szinte minden területén jelentős változásokat eredményezett, így labdarúgásban is. Megjelentek olyan hardver és szoftver lehetőségek, mely megteremtette az objektív elemzés lehetőségét a fejlett technológia támogatásával. A különböző kamerarendszerek, szenzorok és félautomata elemző szoftverek segítségével komplex statisztikai adatgyűjtés valósult és valósul meg napjaink labdarúgásában. Mindezek lehetővé tették, hogy akár valós időben rendelkezésre álljanak az edzők számára a kívánt teljesítmény indikátorok, melyek alapjai lehetnek a döntéshozatalnak. A különböző videóelemző szoftverek mellett leggyakrabban GPS (Global Positioning System - Globális Helymeghatározó Rendszer) rendszert és egyéb szenzorokat használnak a labdarúgó klubok, melyek így rengeteg adattal gazdagodnak (CARROL, 2013). Ezen adatok feldolgozásával a szakemberek elemezhetik a játékosok élettani funkcióit, mozgását, dinamikáját, irányát, ki hány kilométert futott, vagy éppen a taktika kialakítását. A mérkőzések és edzések mellett a teljesítmény mérését szolgálják a laboratóriumi körülmények között végzett vizsgálatok (spiroergometria, tesztösszetétel stb.), melyek szintén rengeteg adatot generálnak egy-egy játékosról. A mérkőzéselemzésből, a GPS mérési és különböző élettani paraméterek adataiból következtethetünk a játékosok fizikai, mentális, taktikai és technikai állapotára. Ezen adatok összességéből generálható egy olyan adatbázis, amelyek hozzájárulhatnak a versenyelőny megteremtéséhez a rivális csapatokkal szemben (BACA, 2015; HUGHES et al., 2015).

A játékos nyomonkövetési rendszerek piaca az elmúlt 10 évben jelentősen növekedett, melynek elsődleges katalizátora, hogy a szakmai munkában résztvevők számára rendkívül fontos információtartalommal bírnak a valós-idejű teljesítmény adatok. Az elmúlt néhány évben vírusszerűen terjedt a felhasználásuk a csapatok által, hogy nyomon kövessék és növeljék a játékosok teljesítményét, továbbá optimalizálják az edzésmunkát. Elsődlegesen a csapatsportok esetén jellemző, azon belül is a labdarúgásnak van a legnagyobb piaca a játékos követő rendszerek alkalmazásában (GVR, 2019). A különböző szövetségek- felismerve a rendszerekben rejlő lehetőségeket - nyitottak voltak a rendszerek alkalmazására és lehetőséget biztosítottak, hogy versenykörülmények közötti használatra. Például a 2018-as oroszországi labdarúgó világbajnokságon bevezettek egy elektronikus teljesíménykövető rendszert (EPTS - Electronic Performance and Tracking System). A Nemzetközi Labdarúgó-szövetség (FIFA) saját fejlesztésű rendszere minden 
résztvevő csapat számára rendelkezésre állt, melynek mért adatait csapatonként három tablet készüléken keresztül biztosították a stábtagok számára. A játékosok különböző teljesítmény mutatóit kamerarendszerek, GPS és egyéb szenzoros (giroszkóp, gyorsulásmérő stb.) rendszerekből nyerték ki, melyeket kiegészítve a mérkőzések felvételeivel biztosítottak a csapatoknak (FIFA, 2018; MEDIAGURU, 2018; VAJNA, 2018). A rendszerekről általánosságban elmondható, hogy valós-idejú teljesítménymutatókat mérnek, videofelvételeket rögzítenek és pozíciós adatokat gyújtenek a játékosokról. Míg korábban ezeket a rendszereket luxuscikkeknek tekintették, addig napjainkra létfontosságú elemekké váltak a labdarúgásban (FIFA, 2018). Szinte minden bajnokságban - akár alacsonyabb osztályokban is - alkalmaznak valamilyen játékoskövető rendszert, melynek leggyakrabban alkalmazott elemei az edzéseken és a mérkőzéseken a GPS alapú nyomon követes és a kamerarendszerek. A nagyobb klubok szakmai stábjaiban külön csapat foglalkozik kifejezetten az adatelemzéssel (TRAINING GROUND GURU, 2019), de ebben a tekintetben még az alacsonyabban rangsorolt bajnokságoknak és csapatainak van lemaradásuk. Jellemzően Magyarországon minden klubnál van legalább egy fő videóelemzésre kijelölt személy, aki egyes esetekben egyéb feladatokat is ellát a klubon belül. A fejlett információtechnológia létjogosultságát felismerték a klubok vezetői és eleinte a versenyelőny megszerzése céljából invesztáltak ezekbe a rendszerekbe, míg napjainkban inkább már a versenyhátrány leküzdése a cél.

\section{A TELJESÍTMÉNYELEMZÉS FOLYAMATA ÉS ESZKÖZEI}

Az elemezés egyre fontosabb elemévé válik a labdarúgásnak napjainkban. A korábbi adatvesztéssel járó, szubjektív, megbízhatatlan elemzési módszereket váltja fel az objektív pontos mérési adatokon nyugvó, megbízható elemzés. A technológia gyors fejlődése, és az objektivitáson alapuló elemzési igény következtében a teljesítmény elemzés folyamatának (1. ábra) egyes fázisaiban jelentős mértékben megjelentek a technológiai eszközök (GONZÁLEZ, 2013). A teljesítmény elemzése az egyik legfontosabb összetevője az edzői munkának (LYLE, 2002). A megfigyelés folyamatában hárul a legnagyobb szerep a játékos nyomon követő rendszerekre. A kamerák felvételei, a különböző szenzorok adatai, az egyéb élettani paramétereket vizsgáló eszközök, vagy mérések adatai mind fontos információval szolgálhatnak a szakmai stáb számára. A teljesítmény elemzés és értékelés során fontos szerepet kapnak azok a szoftverek, melyek a különböző forrásból származó strukturálatlan adatokat feldolgozzák, és elemezhető formába rendszerezik, majd elemzést követően vizualizálják DABNICHKI - BACA, 2008; BACA, 2015). Egy kutatás rávilágított arra, hogy mennyire fontos az objektív elemzés, melyre a technológia használata nélkül még a legkiválóbb edzők sem képesek egy adott mérkőzésen/edzésen. Egy nemzetközi szintű labdarúgó edző egy adott mérkőzés legfontosabb szituációinak csak a 30\%-ra emlékezett vissza, és ennek kevesebb, mint $45 \%$-a volt pontos a mérkőzést követő utóértékelés során. Ugyanakkor 59\%-ra javult az arány, amikor lehetővé tették az edzők számára, hogy jegyzeteljenek mérkőzés közben (FRANKS - MILLER, 1991; LAIRD - WATERS, 2008; HUGHES et al., 2015). Az edzők 
„gyenge" teljesítményének az elsődleges oka az agy működésében keresendő, valamint a mérkőzés során a felfokozott érzelmi állapotnak (GRONLUND et al., 2007). Mindezen adatok egyértelműsítik az objektivitáson alapuló teljesítmény elemzést a labdarúgásban. A teljesítmény növelés szempontjából egy fontos folyamat a visszacsatolás, visszajelzés folyamata (O'DONOGHUE, 2006; SCHMIDT - LEE, 2014), ugyanis a játékosok itt tudják a külső forrásból származó teljesítmény értékeléssel kiegészíteni és objektivizálni a saját percepciójukat (HUGHES et al., 2015). Az elemzésekből (korábbi és adott teljesítmény elemzés) levont következtetések az alapjai a következő edzéseknek, melyek segítségével javítható, és növelhető a teljesítmény.

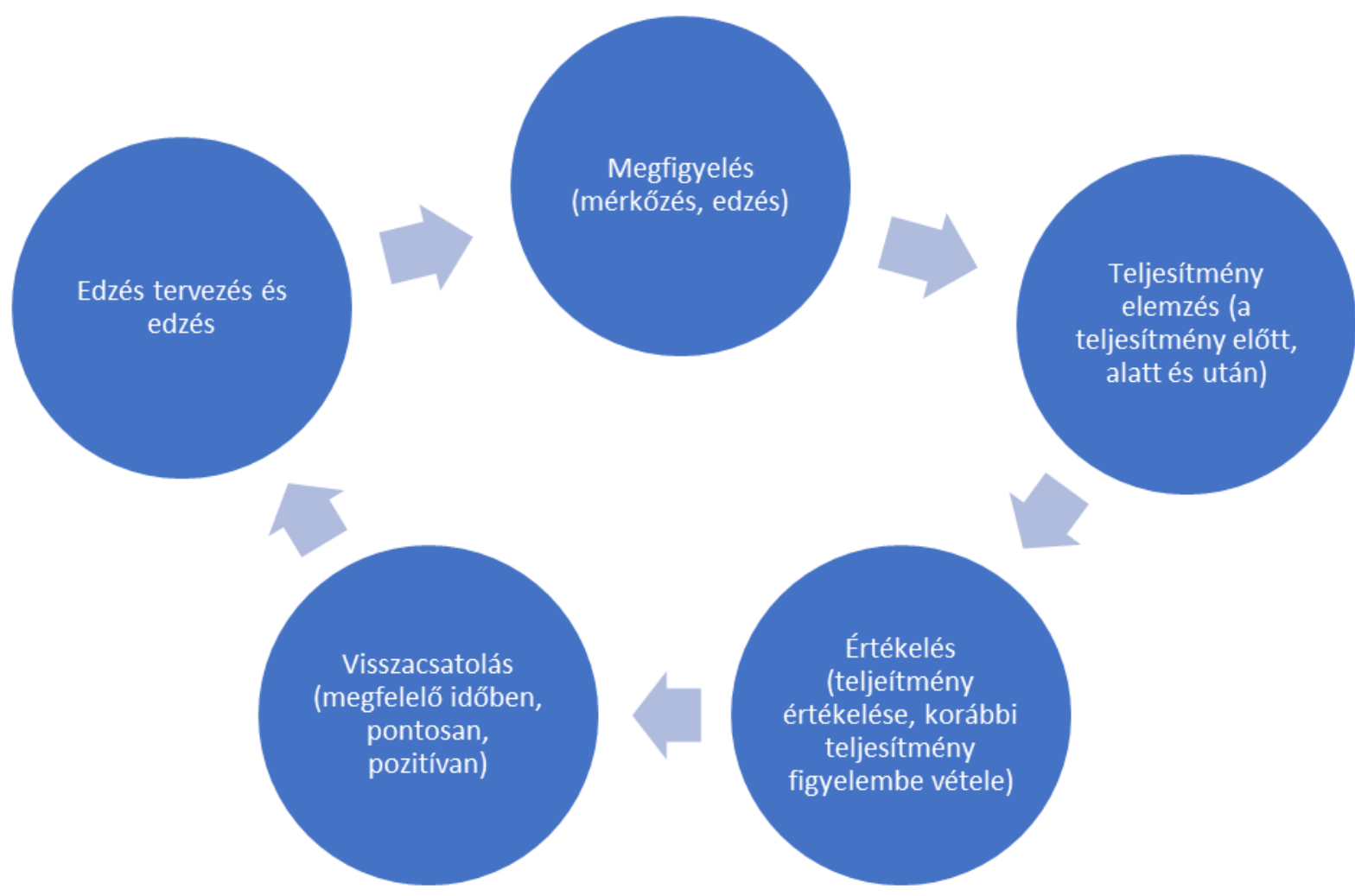

1.ábra: A teljesítmény elemzés folyamata, edzői folyamat modellje Forrás: FRANKS et al., 1983; CRISFIELD et al., 2003; GONZALEZ, 2013

A fejlett technológiát megelőzően a legtöbb edző szóban ismertette a csapattal és a játékosokkal a visszajelzést a teljesítményükről. Napjainkra felértékelődött a vizuális tartalom jelentősége a fiatal generáció számára (lásd YouTube, egyéb közösségi oldalak tartalmai), ezért is fontos a vizuális visszacsatolás a sportolók teljesítményének modellezésére video és képanyag formájában, melyek hatékonyan hozzájárulhatnak a tanulási folyamathoz (VICKERS, 2007; GARCIA-GONZÁLEZ et al., 2013; SCHMIDT - LEE, 2014).

A játékosok számára fontos a visszajelzés módja és annak megfelelő időzítése. A videóelemző által összeállított visszajelzések mennyiségét és összetettségét a játékos, a csapat, vagy éppen a soron következő ellenfél teljesítményéről jelentősen befolyásolja a sportoló képzettségi szintje. Minél képzettebb egy labdarúgó, annál nagyobb mennyiségú és részletesebb visszajelzéseket lehet adni számára (CARLING et al., 2006; CARROL, 2013; 
HUGHES et al., 2015; KOVÁCS, 2018). Általánosságban elmondható, hogy a tanulási folyamat korai szakaszában a nagyobb mennyiségú visszacsatolásnak jótékony hatása van, ugyanakkor a későbbi szakaszban negatívan befolyásolhatja a teljesítményt. Szintén fontos tulajdonsága a visszacsatolásnak, annak gyakorisága, mivel függőséget okozhat a játékosban, mely befolyással lehet a teljesítményére, amennyiben hosszabb ideig nincs visszajelzés a teljesítménnyel kapcsolatban (CARROL, 2013).

A teljesítmény visszajelzés időpontjának kiválasztása is fontos szempont az edző számára (MASLOVAT et al., 2009). A technológia lehetővé tette, hogy akár már mérkőzés félidejében is visszanézzék a legfontosabbnak vélt mérkőzés kimenetelét befolyásoló kulcsszituációkat. A valós idejű elemzés és az azonnali digitális tartalommal támogatott visszacsatolás napjaink labdarúgásában egyre inkább elterjedőben van. Természetesen nem csak mérkőzések alkalmával használják, hanem gyakran az edzéseken is bevetik ezen lehetőségeket egy-egy fontosabb szituáció hibajavításánál. Leggyakrabban a teljesítmény utólagos értékelését végzik, amikor rendelkezésre áll a megfelelő mennyiségú idő a visszajelzés elkészítésére (HUGHES et al., 2015).

\section{GPS ÉS EGYÉB SZENZOROK}

A GPS technológia a legelterjedtebb módszer a játékosok követésére az alacsony költsége miatt. A GPS készüléket a játékosok magukon viselik, valamilyen speciális rögzítés (mellény) segítségével általában a háton. A GPS jelek segítségével, melyet a játékos által viselt eszköz kibocsát meg lehet határozni a megtett távolságot, melyből ki lehet számítani a sebességet is. Az adatok vezeték nélküli kapcsolaton keresztül jutnak el közvetlenül a számítógéphez, ahol egy arra alkalmas szoftver feldolgozza és vizualizálja. Az olyan GPS eszközök melyek már alkalmasak a sportteljesítmények vizsgálatára drágábbak és a mintavételi arányuk is nagyobb a hagyományos GPS eszközökkel szemben $(5-10 \mathrm{~Hz}-1$ $\mathrm{Hz}$ ). A még pontosabb mérések érdekében a GPS alapú nyomonkövető rendszereket kiegészítik egyéb szenzorokkal, mint például gyorsulásmérő, vagy giroszkóp. Ezen szenzorok még magasabb mintavételi frekvencián múködnek $(100 \mathrm{~Hz})$ (HOLANEK, 2014; JULIEN, 2019). A szenzorok adataiból egy algoritmus segítségével számszerűsíthetővé válnak a sportoló által a tér minden irányába végzett úgynevezett mikromozgások. Ilyen lehet például a gyorsulás, a lassulás, az oldalirányú elmozdulások, a felugrások és leérkezések (JULIEN, 2019). A GPS rendszerek hátránya lehet a külső körülményekre való érzékenységük, például a jelerősség csökken nagyobb épületek környezetében, de szintén befolyásolja a múködést az aktuális légköri viszonyok. Ezek mellett az eszközök viseléséből származó kellemetlenségekkel is meg kell küzdeniük a sportolóknak. Szintén hátránya a rendszereknek, hogy a sporttevékenységtől függően maga a viselt eszközben is probléma merülhet fel (árnyékolás, takarás). A mérkőzés elemzése során az egyéb szenzorokkal kiegészített rendszerek a terhelés időtartamát, a megtett távolságot, az átlagsebességet, a különböző intenzitással végzett tevékenységeket (pl. a közepes intenzitásban, vagy éppen sprintben megtett távolságokat), a maximális sebességet, a gyorsulások, lassulások számát és mértéké, a felugrások mértékét és számát, vagy éppen 
a nagy intenzitású irányváltások számát (EDGECOMB - NORTON, 2006; HOLANEK, 2014; BALOGH et al., 2016).

Ezen paraméterek vizsgálatával, akár azonnali visszacsatolásra is képes lehet a szakmai stáb, de az adatok megfelelő elemzése és értékelése révén optimalizálni lehet a játékosok terhelését és felkészülését. A nemzetközi referencia adatok segítségével egyénre és pozícióra szabva lehet az edzéseket felépíteni, ezáltal növelve a csapat és a sportoló teljesítményét. Az adatok által hozzájuthatunk olyan értékes információhoz, mellyel a sérüléseket meg lehet előzni és természetesen a taktikai, technikai elemeket is lehet ezáltal fejleszteni (BALOGH et al., 2016).

\section{VIDEÓELEMZŐ RENDSZEREK.}

A legismertebb piacon elérhető videóelemző szoftverekről általánosságban elmondható, hogy működésüket tekintve hasonlóak. Mindegyik esetén az egyik legfontosabb funkció a videók egy bizonyos szempontrendszer alapján történő jelölése és ez alapján részletes statisztika készítése. Ezek mellett, az eszközök segítségével sokkal könnyebben lehet videóanyagokat, videoklipeket összeállítani (le lehet szűrni a jeleneteket csapat, játékos, esemény szinten), ezekben a videókban egyéb akár külső tartalmakat elhelyezni, vagy éppen ezeken a felületeken rajzfunkció, vagy animáció segítségével taktikai képeket, animációkat készíteni. Vannak olyan szoftverek, melyek támogatják a 3D tartalmak előállítását, mely hozzájárulhat a szemléltetés még intenzívebbé tételéhez és segítheti a játékosok jobb megértését. A gyakran felhő alapú szolgáltatást is kínáló szoftverek segítségével könnyen megoszthatjuk akár a személyre szabott tartalmainkat a játékosokkal. Egyes szoftverek outputjainál figyeltek arra, hogy kompatibilis formátumban kinyerhetőek legyenek az adatok, ugyanis rájöttek arra, hogy egy-egy videóelemző nem feltétlenül csak egy szoftverrel dolgozik. Bizonyos szoftvermegoldások nagy előnye, hogy testre szabható, azaz nem sportágfüggő, ezáltal rugalmasságot ad a felhasználói számára. Vannak olyan megoldások is a piacon melyek online elemzést biztosítanak, sőt lehetőséget arra, hogy egy független professzionális elemző stábra bízzuk az elemzési folyamatot, mely rövid időn belül elkészíti a kért elemzést. A legismertebb videóelemző szoftverek: Sportscode, LongoMatch, Dartfish, Hudl, Nacsport (hudl.com; nacsport.com; longomatch.com; dartfish.com). Fontos megjegyezni, hogy az előbb felsorolt szoftverek elsősorban a klubok saját szempontrendszer szerinti elemzéseihez és videóanyagok összeállításához nyújtanak segítséget, míg vannak kifejezetten a sportra szakosodott elemző és adatszolgáltató cégek, melyek termékeiket (adatok, elemzések) értékesítik a csapatok számára (Opta, InStat) (optasports.com; instatsport.com; DINITA, 2019).

\section{DRÓNOK}

A labdarúgásban is megjelent a drón technológia az elmúlt években. Több klubcsapat is megpróbálja kiaknázni az ebben rejlő lehetőségeket. A drón és a rajta található jó minőségű kamera segítségével madártávlatból nyílik lehetőségük a csapat edzését rögzíteni. A felülnézeti videóanyag révén a szakmai stáb fel tudja hívni a játékosok 
figyelmét a különböző helyezkedési problémákra, vagy éppen a csapatrészek együttes mozgásának hiányosságaira, melyek az oldalvonalról vizsgálva nem láthatóak, ezzel is elkerülve a teljesítmény téves értékelését és rossz elemzését. Természetesen ezen videóanyagok esetén is lehetőség van azok tárolására, adatbázisba rendezésére, továbbá a videóanyagok vágása révén a csapat, csapatrészek és egyének szintjén is rendelkezésére lehet bocsátani, ezzel hozzájárulva a tanulási és fejlesztési folyamathoz. A drón technológia egyik legnagyobb hátránya az akkumulátor kapacitása, mely nem teszi lehetővé egy edzés teljes felvételét (POWDERLY, 2016; ZSÉDELY, 2016).

\section{ÖSSZEFOGLALÁS}

Az elmúlt 30 év dinamikus technológiai fejlődése jelentős változások eredményezett a sportban és így a labdarúgásban is. Ezeket a technológiai újítások lehetővé tették a játékosok teljesítményének, illetve élettani paramétereinek a monitorozását. Az adatok gyűjtésének elsődleges célja mindig a csapat, vagy játékos teljesítményének fokozása és az ellenfelekkel szemben a versenyelőny kialakítása volt. A labdarúgást szinte teljesen átitatta a technológiai forradalom és az elmúlt években egyre inkább adatorientált sportággá alakult. Ennek eredményeképpen egyre több sporttudományi szakembert (videóelemző adatelemző stb.) foglakoztatnak a klubok, hogy folyamatosan növekvő mennyiségú adatot begyújtsék, feldolgozzák, elemezzék és vizualizálják a szakmai stáb részére. A szakemberek rendelkezésére álló eszköztár (GPS, drónok, videóelemző szoftverek) folyamatos fejlődik, bővül, aminek köszönhetően több adatot tudnak generálni. Kijelenthetjük tehát, hogy a 21.-ik század labdarúgásában elengedhetetlen a technológia hiánya. Mára már elképzelhetetlen egy videóelemző szakember jelenléte a szakmai stábban, ami a jövőben csak gyarapodni fog, a következő években akár már minden profi játékos felkészülését saját videóelemző fogja nyomon követni. A technológia az évek előrehaladtával egyre jobban szerves részét fogja alkotni a labdarúgásnak, amelynek köszönhetően egyre nagyobb és részletesebb adatbázissal fogunk rendelkezni a csapatokról, illetve a játékosokról, véleményem szerint ez a labdarúgás jövője.

A publikáció elkészitését az EFOP-3.6.1-16-2016-00022 „Debrecen Venture Catapult Program" projekt támogatta. A projekt az Európai Unió támogatásával, az Európai Szociális Alap társfinanszírozásával valósult meg.

\section{IRODALOMJEGYZÉK}

Baca A. (Edited) (2015). Computer science in sport: research and practice, Routledge, ISBN: 978-0-415-71545-4

Balogh L., Molnár A., Jenei Z., Nábrádi Zs., Ráthonyi G., Szilágyi R. \& Balogh P. (2016). Bevezetés a sportdiagnosztikába, Campus Kiadó, Debrecen 
Carling C., Williams M.A. \& Reilly T. (2006). Handbook of Football Match Analysis, Routledge, London, 184 pp., ISBN 0-203-44862-6

Carrol R. (2013). An experts guide for performance analysis E-book. Retrieved from https://thevideoanalyst.com/wp-content/uploads/2013/07/Full-Ebook.pdf

Crisfield P., Crabral P., \& Carpenter, F. (2003). The successful coach: Guidelines for coaching practice, (3rd ed.), Leeds: Coachwise/SportsCoach UK.

Dabnichki P., Baca A. (2008). Computers in Sport, WITpress, Southampton, ISBN: 978-184564-064-4

Dinita M. (2019). Best soccer analysis software for PC [2020 Guide]. Retrieved from https://windowsreport.com/football-anyalysis-software/

Edgecomb S. T.\& Norton K. I. (2006). Comparison of global positioning and computerbased tracking systems for measuring player movement distance during Australian Football, Journal of Science and Medicine in Sport, 9, 25-32.

FIFA (2018). EPTS Electronic Performance and Tracking Systems. Retrived from https://soccer-technology.fifa.com/en/media-tiles/epts/

Franks I.M., Goodman D.\& Miller, G. (1983). “Analysis of Performance: Qualitative or Quantitative", in SPORTS

Franks I.M., Miller, G. (1991). Training coaches to observe and remember. Journal of Sport Sciences, 9, 285-297.

García-González L., Moreno M.P., Moreno A., Gil A. \& del Villar F. (2013). Effectiveness of a video-feedback and questioning programme to develop cognitive expertise in sport. PloS one, 8(12), e82270. https://doi.org/10.1371/journal.pone.0082270

González D.E.L. (2013). Wrestler's performance analysis through notational techniques. International Journal of Wrestling Science, 3, (29), 68-89. DOI:

10.1080/21615667.2013.10878990

Grand View Research (2019). Player Tracking System Market Size, Share \& Trends Analysis Report By Offering (Solution, Services), By Technology (Optical, Wearables), By End Use (Individual, Team Sports), By Region, And Segment Forecasts, 2019 - 2025. Grand View Research

Gronlund S.D., Carlson C.A. \& Tower D. (2007). Episodic Memory. Handbook of Applied Cognition: Second Edition. John Wiley and Sons. 111-136.

Holanek Z. (2014). Mérkőzés- és teljesítményanalízis GPS és Polar rendszerrel, UEFA Coaching Programme

Hughes M., Franks I.M. (2015). Essentials of Performance Analysis in Sport. London: Routledge, DOI: 10.4324/9781315776743 
Julien C. (2019). What is IMA? Retrieved from https://support.catapultsports.com/hc/enus/articles/360000510856-What-is-IMA-

Kovács G. (2018). Miből, mikor és mennyit? - Így tervezzünk meg egy labdarúgó edzést. Retrieved from http://blog.soccerfactor.hu/mibol-mikor-es-mennyit-igy-tervezzunkmeg-egy-labdarugo-edzest/

Laird P., Waters L. (2008). Eyewitness recollection of sport coaches. International Journal of Performance Analysis in Sport, 8, 76-84. DOI: 10.1080/24748668.2008.11868424

Lyle J. (2002). Sport Coaching Concepts: A framework for coaches' behaviour. London: Routledge, 343 p. ISBN: 0415261570

Mackenzie R. \& Cushion, C. (2012). Performance analysis in football: A critical review and implications for future research. Journal of Sports Sciences, 31. 10.1080/02640414.2012.746720.

Maslovat D., Brunke K.M., Chua R., \& Franks I.M. (2009). Feedback Effects on Learning a Novel Bimanual Coordination Pattern: Support for the Guidance Hypothesis. Journal of Motor Behavior, 41,(1), 45-54. DOI: 10.1080/00222895.2009.10125923

MEDIAGURU (2018): 5 Technology Innovations in the 2018 FIFA World Cup. Retrieved from https://www.mediaguru.com/5-technology-innovations-in-the-2018-fifa-world-

cup/

O'Donoghue P. (2006). The use of feedback videos in sport. International Journal of Performance Analysis in Sport, 6(2), 1-14.

Powderly D. (2016). Drones In football. Retrieved from https://medium.com/@David Powderly/drones-in-soccer-65e275681eba

Schmidt R.A., \& Lee T.D. (2014). Motor learning and performance: From principles to application. Champaign, IL: Human Kinetics. ISBN: 9781450443616

TRAINING GROUND GURU (2019). Manchester City create new first team data science role. Retrieved from https://trainingground.guru/articles/manchester-city-create-newfirst-team-data-science-role

Vajna T. (2018). EPTS, VAR, 5000 dolláros Hublot okosóra: a futballvébé megkerülhetetlen szereplője lett a high tech. Retrieved from https://qubit.hu/2018/06/15/epts-var-5000-dollaros-hublot-okosora-a-futballvebemegkerulhetetlen-szereploje-lett-a-high-tech

Vickers J.N. (2007). Perception, Cognition, and Decision Training. The Quiet Eye in Action. Champaing, IL:Human Kinetics. 273 p. 
Vol 3, No 1 (2020): Stadium -Hungarian Journal of Sport Sciences https://doi.org/10.36439/SHJS/2020/1/5429

Zsédely P. (2016). Labdarúgás: drónokkal a jobb csapatteljesítményért. Retrieved from http://sportsmarketing.hu/2016/05/27/labdarugas-dronokkal-a-jobbcsapatteljesitmenyert/ 